\title{
Analysis of selected glutathione $S$-transferase gene polymorphisms in Malaysian type 2 diabetes mellitus patients with and without cardiovascular disease
}

A. Etemad ${ }^{1}$, R. Vasudevan ${ }^{2 *}$, A.F.A. Aziz ${ }^{3}$, A.K.M Yusof ${ }^{4}$, S. Khazaei ${ }^{1}$, N. Fawzi ${ }^{5}$, S. Jamalpour ${ }^{1}$, M. Arkani ${ }^{1}$, N.A. Mohammad ${ }^{1,2}$ and P. Ismail ${ }^{1 *}$

${ }^{1}$ Genetic Research Group, Department of Biomedical Science,

Faculty of Medicine and Health Sciences, Universiti Putra Malaysia, Serdang, Selangor, Malaysia

2Malaysian Research Institute of Aging, Universiti Putra Malaysia, Serdang, Selangor, Malaysia

${ }^{3}$ Department of Medicine, Faculty of Medicine and Health Sciences, Universiti Putra Malaysia, Serdang, Selangor, Malaysia

${ }^{4}$ Department of Cardiology, Institut Jantung Negara - National Heart Institute, Kuala Lumpur, Selangor, Malaysia

${ }^{5}$ Management \& Science University, University Drive, Off Persiaran Olahraga,

Shah Alam, Selangor, Malaysia

*These authors contributed equally to this study.

Corresponding author: P. Ismail

E-mail: patimahismail@gmail.com

Genet. Mol. Res. 15 (2): gmr.15025845

Received September 10, 2015

Accepted October 22, 2015

Published April 7, 2016

DOI http://dx.doi.org/10.4238/gmr.15025845

ABSTRACT. Type 2 diabetes mellitus (T2DM) is believed to be associated with excessive production of reactive oxygen species. Glutathione $S$-transferase (GST) polymorphisms result in decreased or absent enzyme activity and altered oxidative stress, and have been associated with cardiovascular disease (CVD). The present study assessed the effect 
of GST polymorphisms on the risk of developing T2DM in individuals of Malaysian Malay ethnicity. A total of 287 subjects, consisting of 87 T2DM and 64 CVD/T2DM patients, as well as 136 healthy gender- and agematched controls were genotyped for selected polymorphisms to evaluate associations with T2DM susceptibility. Genomic DNA was extracted using commercially available kits, and GSTM1, GSTT1, and $\alpha$-globin sequences were amplified by multiplex polymerase chain reaction. Biochemical parameters were measured with a Hitachi autoanalyzer. The Fisher exact test, the chi-square statistic, and means \pm standard deviations were calculated using the SPSS software. Overall, we observed no significant differences regarding genotype and allele frequencies between each group $(P=0.224$ and 0.199 , respectively). However, in the combined analysis of genotypes and blood measurements, fasting plasma glucose, $\mathrm{HbA}_{1 \mathrm{c}}$, and triglyceride levels, followed by age, body mass index, waist-hip ratio, systolic blood pressure, and history of T2DM significantly differed according to GST polymorphism ( $P<0.05$ ). Genetically induced absence of the GSTT1 enzyme is an independent and powerful predictor of premature vascular morbidity and death in individuals with T2DM, and might be triggered by cigarette smoking's oxidative effects. These polymorphisms could be screened in other ethnicities within Malaysia to determine further possible risk factors.

Key words: Glutathione S-transferase; Cardiovascular disease; Malaysia; Type 2 diabetes mellitus

\section{INTRODUCTION}

Type 2 diabetes mellitus (T2DM) is one of several serious chronic diseases linked to coronary heart disease (CHD), and its associated complications make it a key contributing factor to mortality. Circumstances such as age, gender, ethnicity, lifestyle, and genetic background, as well as their interactions with each other and the environment play a crucial role in the occurrence of T2DM. The International Diabetes Federation (IDF) has predicted that the number of people with diabetes will rise from 285 million in 2010 to 439 million in 2030. In Malaysia, the proportion of known diabetes is estimated to have increased from 6.5 to $9.5 \%$, accompanied by a three-fold enlargement in newly diagnosed cases from 1.8 to $5.4 \%$ over the same period (Letchuman et al., 2010; Etemad et al., 2013; Haghvirdizadeh, et al., 2015). Malaysia has different subethnic groups (Hatin et al., 2014). In 2011, an identical trend was observed, in which the total Malaysian diabetes population, consisting of known and newly diagnosed cases, increased from 11.7 to $13.3 \%$ by 2030 (Whiting et al., 2011). According to the latest National Health Morbidity Survey in 2006, the prevalence of T2DM among adults was found to be $14.9 \%$ in Malaysia (Malaysian Ministry of Health, 2008).

Obesity and insulin resistance are risk factors for cardiovascular disease (CVD) and T2DM, and may be affected by oxidative stress. In addition, sequence variations in genes encoding glutathione S-transferases (GSTs) have been shown to be strongly associated with CVD and T2DM risk, making them an interesting focus of investigation.

GSTs were first discovered in animal studies during the 1960s and were recognized for their importance in the metabolism and detoxification of drugs (Wilce and Parker, 1994). The 
GST family includes enzymes essential for the protection of nucleophilic centers in DNA and proteins from modification by electrophiles (Ketterer et al., 1992). These isoenzymes are widely distributed in nature, being found in various organisms including microorganisms, insects, plants, birds, and mammals (Hayes and McLellan, 1999). They are grouped into three main categories, namely cytosolic, mitochondrial (which together are known as the soluble GSTs), and microsomal (insoluble) GSTs (Jacobsen et al., 2002). The soluble GSTs are involved in the metabolism of foreign chemicals, such as carcinogens, environmental pollutants, and chemotherapeutic drugs (Hayes and McLellan, 1999), making them a worthwhile study subject.

The GST gene cluster located in the $\mathrm{p} 13.3$ region of chromosome 1 is involved in carcinogen metabolism and protection against oxidative stress (Pearson et al., 1993). Polymorphisms in these enzyme-encoding genes have been associated with diseases such as cancer (Forsberg et al., 2001). The composition of GSTs varies between tissues, with particular combinations being expressed, potentially influencing detoxification capability (Eaton and Bammler, 1999).

\section{MATERIAL AND METHODS}

Ethical approval for this study was obtained from the Faculty of Medicine and Health Sciences, Universiti Putra Malaysia [Ref No. JSB_Mac (12)02], and the National Heart Center Institute Kuala Lumpur [IJN; Ref No. IJNEC/05/10 (02)].

The study included 287 subjects, of which 87 were T2DM and 64 were CVD/T2DM patients and 136 healthy controls. The patient group consisted of individuals having attended IJN for their CVD/T2DM treatment, and were included based on IDF criteria. Subjects were adults $\geq 30$ years old having been determined as suffering from T2DM based on their medical records, and unrelated healthy individuals recruited as general health check-up subjects and matched with cases by age, gender, and race.

Three to five milliliters of peripheral blood was drawn from participants using a 21-gauge needle by a qualified phlebotomist. Plasma was separated from the blood by centrifugation and stored at $-20^{\circ} \mathrm{C}$ for later biochemical analysis. Each individual's weight and height were recorded to calculate their body mass index (BMI). Plasma samples were analyzed on a Hitachi 912 autoanalyzer (Hitachi, Düsseldorf, Germany) using kits supplied by Roche Diagnostics (Mannheim, Germany) to determine levels of triglycerides (TGs), high density lipoprotein (HDL), total cholesterol, and low density lipoprotein. Lipid profiles were classified according to the guidelines of the Third Report of the National Cholesterol Education Program (Grundy, 2008). Blood biochemical analyses were performed after collection of overnight fasting (10 to $14 \mathrm{~h}$ ) blood specimens.

DNA was extracted from blood with a commercially available DNA extraction kit (innuPREP Blood DNA Mini Kit; Analytik Jena, Germany), following the manufacturer protocol. The quality of extracted DNA was evaluated by $0.8 \%$ agarose gel electrophoresis, while quantity was measured by absorbance at 260 and $280 \mathrm{~nm}$ using a NanoDrop (Thermo Scientific, Waltham, MA, USA).

Multiplex polymerase chain reaction (PCR) consists of the simultaneous amplification of different loci of interest in the same reaction tube (Sadi et al., 2008). The reaction was performed by adding the selected primers (for GSTT1, GSTM1, and $\alpha$-globin) into the master mix. Each reaction contained $13.4 \mu \mathrm{L}$ distilled $\mathrm{H}_{2} \mathrm{O}$ and $10 \mu \mathrm{L}$ 1X PCR buffer (G-2000; GENETBIO, Inc., Daejeon, Korea), consisting of $1 \mathrm{U}$ Taq DNA polymerase (GENETBIO), $20 \mathrm{mM}$ Tris- $\mathrm{HCl}, 80 \mathrm{mM}$ $\mathrm{KCl}, 4 \mathrm{mM} \mathrm{MgCl}_{2}$, enzyme stabilizer, and loading, $\mathrm{pH}$ 9.0. In addition, dATP, dCTP, dGTP, and dTTP (each at $0.5 \mathrm{mM}$ ) were included, together with forward and reverse primers (both $0.1 \mu \mathrm{L}$ at $10 \mu \mathrm{M})$. Finally, $1 \mu \mathrm{L}$ template DNA (100 $\mathrm{ng} / \mu \mathrm{L})$ was added to each reaction tube. Different 
cycling conditions were used for optimal amplification of target sequences (Table 1). Reagents and PCR conditions were optimized to achieve amplification products lacking non-specific bands and corresponding to those expected.

Table 1. Genes examined in this study, with details of single nucleotide polymorphism ID, polymerase chain reaction primers, cycling conditions, and expected product sizes.

\begin{tabular}{|c|c|c|c|c|c|}
\hline Gene & SNP & Forward and reverse primers & $\begin{array}{l}\text { PCR product } \\
\text { size (bp) }\end{array}$ & Cycling conditions & Reference \\
\hline GSTT1 & rs470264 & $\begin{array}{l}\text { 5'-TTCCTTACTGGTCCTCACATCTC-3' } \\
\text { 5'-TCACCGGATCATGGCCAGCA-3' }\end{array}$ & 480 & \multirow{3}{*}{$\begin{array}{l}95^{\circ} \mathrm{C} \text { for } 5 \mathrm{~min} \\
30 \mathrm{cycles}: \\
95^{\circ} \mathrm{C} \text { for } 45 \mathrm{~s} \\
62^{\circ} \mathrm{C} \text { for } 30 \mathrm{~s} \\
72^{\circ} \mathrm{C} \text { for } 45 \mathrm{~s} \\
2^{\circ} \mathrm{C} \text { for } 10 \mathrm{~min} \\
4^{\circ} \mathrm{C} \text { hold }\end{array}$} & 't Hoen et al., 2002 \\
\hline GSTM1 & rs745723 & $\begin{array}{l}\text { 5'-GAACTCCCTGAAAAGCTAAAGC-3' } \\
\text { 5'-GTTGGGCTCAAATATACGGTGG-3' }\end{array}$ & 215 & & Ramprasath et al., 2011 \\
\hline$\alpha$-globin & - & $\begin{array}{l}\text { 5'-CAACTTCATCCACGTTCACC-3' } \\
\text { 5'-GAAGAGCCAAGGACAGGTAC-3' }\end{array}$ & 265 & & Amer et al., 2011 \\
\hline
\end{tabular}

$\mathrm{SNP}=$ single nucleotide polymorphism; $\mathrm{PCR}=$ polymerase chain reaction

PCR products were mixed with $2 \mu \mathrm{L} 1 \mathrm{X}$ UltraPower loading/staining dye (BioTek, Beijing, China) and separated by $2 \%$ agarose gel electrophoresis, before being visualized under ultraviolet light using an Alphalmager (Alpha Innotech, San Leandro, CA, USA), with which images were captured (Figure 1).

As described by Zeggini et al. (2008), approximately $10 \%$ of samples, corresponding to three of the GST polymorphism genotypes, were chosen and genotyped again using the same assay. We observed complete agreement with the previous sample amplification results. Moreover, these duplicate samples were amplified and the results scored by another operator.

Statistical analyses were carried out using SPSS (version 21; IBM Corp., Armonk, NY, USA). Continuous variables were examined for skewness and if needed, values were logarithmically transformed to achieve a normal distribution. A normality test was conducted to assess the distribution of variables, with those that failed and outliers being excluded from further analysis. A chi-square test was used by means of cross tabulation for comparing the frequencies or proportions of qualitative variables in groups, determining whether genotype frequencies were in Hardy-Weinberg equilibrium (HWE), and comparing allele and genotype frequencies between groups and their significance (based on $\mathrm{P}<0.05$ being considered statistically significant). Frequencies were assessed using descriptive statistics and the general linear model. In addition, gel electrophoresis banding patterns were scored with UVIdoc Version 98 (UVItec, Cambridge, UK), and sorted into Excel format prior to statistical analysis.

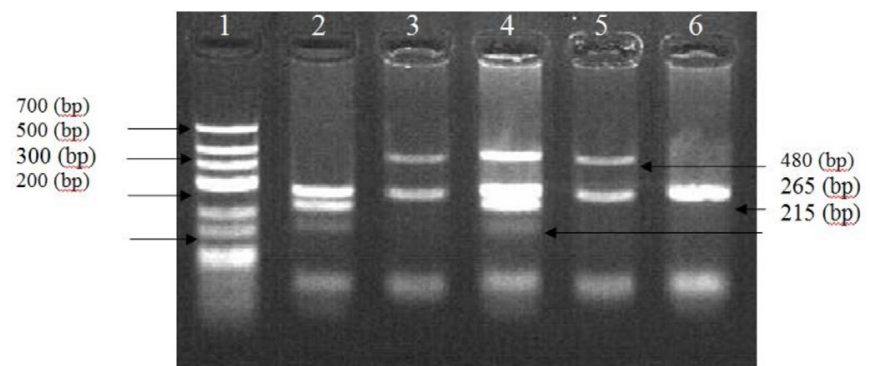

Figure 1. GSTT1/GSTM1 banding pattern on a $2 \%$ agarose gel. The presence of wild-type GSTT1 and GSTM1 was detected by bands at 480 and $215 \mathrm{bp}$, respectively, with a lack of such bands indicating their absence. $\alpha$-globin was used as an internal positive control (265 bp). Lane 1 = DNA ladder (25 to $700 \mathrm{bp}$ ); lane 2 = GSTT1 null genotype; lanes 3 and 5 = GSTM1 null genotype; lane 4 = GSTM1 and GSTT1 wild-type genotype; lane 6 = GSTM1 and GSTT1 null genotype . 


\section{RESULTS}

In this study, 174 men (60.6\%) and 113 women (39.4\%) were evaluated. Comparison of clinical characteristics of T2DM $(\mathrm{N}=87)$ and T2DM/CVD patients $(\mathrm{N}=64)$ and controls $(\mathrm{N}=136)$ was carried out. Genotype distributions were found to be in agreement with HWE. The frequency of GSTM1 and GSTT1 single-null genotypes was 48.1 and $16.5 \%$ in the control group, 32.5 and $17.5 \%$ among T2DM patients, and 45.0 and $11.7 \%$ in T2DM/CVD subjects, respectively.

In this study, the detection of three gel bands was used for genotyping, namely those of $480 \mathrm{bp}$ (indicating GSTT1 presence), $215 \mathrm{bp}$ (signifying the presence of GSTM1), and $265 \mathrm{bp}$ (the $\alpha$-globin gene positive control, which was detected in all individuals). Genotype and allele frequencies of the GST genes tested are shown in Table 2. The presence and absence of wild-type sequences is represented as "+" and "-", respectively, in the order GSTT1/GSTM1, such that "+/-" signifies the presence of GSTT1 and the absence of GSTM1 (Figure 1).

GST polymorphism genotype and allele frequencies did not significantly differ between the groups ( $P=0.224$ and 0.119 ), as shown in Table 2 . The impact of these polymorphisms on clinical factors was assessed (Table 3). Significant differences were noted when comparing CVD patients with and without T2DM to healthy individuals in age, fasting plasma glucose (FPG), glycated hemoglobin $\left(\mathrm{HbA}_{1 \mathrm{c}}\right)$, TGs, waist-hip ratio $(\mathrm{WHR})$, and family history of diabetes $(\mathrm{P}<$ $0.019)$, followed by systolic blood pressure (SBP) and BMI; $(P<0.05)$.

More interestingly, in regard to the influence of GST genotype, the lowest BMI value among the control subjects belonged to the +/- group (26.50 \pm 4.89$)$, while the highest figure for the T2DM patients was observed in those carrying the $-/+$ genotype $(29.40 \pm 5.85)$. BMI in the CVD/T2DM cases was lowest for those with a +/+ genotype $(26.14 \pm 3.52)$ and highest in the $+/$ - group (28.99 \pm 4.01$)$. The most elevated FPG levels were associated with the $+/+$ genotype in the CVD/T2DM group $(11.25 \pm 4.67)$ and the + - genotype for the T2DM group $(9.21 \pm 3.83)$, with this latter genotype demonstrating the lowest FPG among the control subjects (4.95 \pm 1.01$)$. The $+/+$ genotype in the CVD/T2DM group was associated with the highest values for SBP (150.00 \pm 20.29), diastolic blood pressure (83.44 \pm 8.63), FPG (11.25 \pm 4.67$)$, and $\mathrm{HbA}_{1 \mathrm{c}}(9.10 \pm 2.12)$ of all three groups. Furthermore, also among CVD/T2DM subjects, the -/+ genotype demonstrated the lowest HDL $(0.85 \pm 0.05)$ and highest TG values $(2.15 \pm 1.50)$ observed. Family history of diabetes significantly differed between all groups $(P=0.019)$ and a post hoc test revealed a significant difference within the T2DM group in addition $(P=0.007$; Table 3$)$.

Table 2. Genotype and allele distributions of GST genes in Malaysian subjects.

\begin{tabular}{|c|c|c|c|c|c|}
\hline & \multicolumn{4}{|c|}{ Genotype frequency (\%) } & \multirow[t]{2}{*}{$P$ value } \\
\hline & GSTTIGSTM (+/-) & GSTTIGSTM $(-/+)$ & GSTTIGSTM (-I-) & GSTTIGSTM $(+/+)$ & \\
\hline Control $(\mathrm{N}=136)$ & 48.1 & 16.5 & 17.3 & 18.0 & \\
\hline T2DM (N = 87) & 32.5 & 17.5 & 27.5 & 22.5 & 0.224 \\
\hline \multirow[t]{3}{*}{ T2DM/CVD $(\mathrm{N}=64)$} & 45.0 & 11.7 & 28.3 & 15.0 & \\
\hline & \multicolumn{4}{|c|}{ Allele frequency } & \\
\hline & & GSTT & GSTM & & \\
\hline Control & & 0.657 & 0.342 & & \\
\hline T2DM & & 0.575 & 0.425 & & 0.119 \\
\hline T2DM/CVD & & 0.666 & 0.333 & & \\
\hline
\end{tabular}

$P$ values were calculated by chi-square test with a $2 \times 2$ contingency table, and those $<0.05$ were considered significant. The presence or absence of each gene is signified by "+" and "-", respectively. T2DM = type 2 diabetes mellitus, CVD = cardiovascular disease. 
A. Etemad et al.

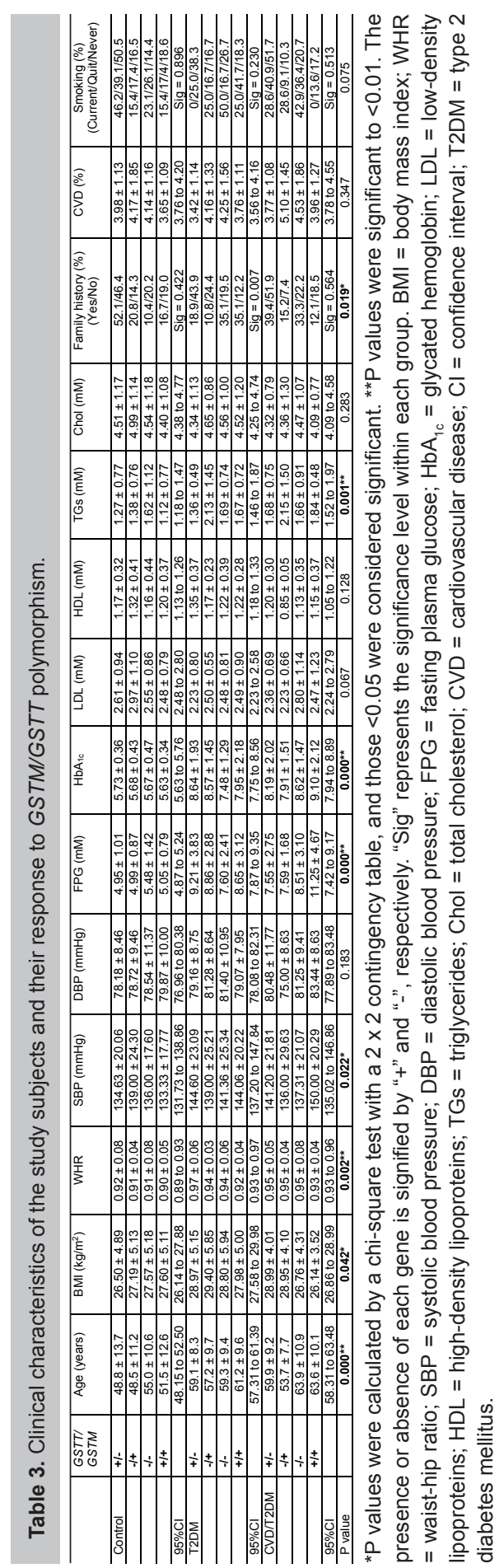




\section{DISCUSSION}

Polymorphisms of GSTM1 are among the most studied GST variants for disease susceptibility (Ketterer et al., 1992). It is believed that deletion of the entire gene completely eliminating enzyme activity has significant effects on carcinogen metabolism. The pancreas plays an important role in blood glucose control and is affected by carcinogens present in cigarette smoke, making it susceptible to the development of cancer. Moreover, due to the lack of available human donors, it is increasingly necessary to investigate alternative sources, such as cultured islet cells, for future pancreatic transplantation (Hani et al., 2010). GSTM1 polymorphisms have been extensively studied in gastric (La Torre et al., 2005), colon (Ye and Parry, 2003), head and neck (Hashibe et al., 2003; Ye et al., 2004), prostate (Ntais et al., 2005), lung (Benhamou et al., 2002), bladder (Johns and Houlston, 2000), and breast cancer (Sull et al., 2004; Vogl et al., 2004).

Several GST polymorphisms have been associated with various diseases and different susceptibility rates. Those of GSTM1 and GSTT1, important members of the GST family, can lead to a complete lack of the corresponding protein (Pemble et al., 1994). The GSTT1 null and GSTT1/ GSTM1 double-null genotypes have been recognized as genetic risk factors, principally through their interaction with current smoking status, exerting a synergistic effect on the development of T2DM and its CVD complications (Doney et al., 2005; Hori et al., 2007). As regulation of GST genes varies significantly between tissues, and diet or mutations in GSTM1 and GSTT1 are able to modulate their expression, it seems difficult to accurately predict the degree to which any GST gene is expressed in a given tissue (Eaton and Bammler, 1999).

Pemble et al. (1994) reported that approximately $20 \%$ of the white population is homozygous for a null variant of GSTT1, which is consistent with our findings (17.3 to $28.3 \%$ ). The role of GSTT1 in deactivating the epoxides in cigarette smoke, together with its absence in smoking-related cancers, suggests that individuals homozygous for the null allele may be at higher risk of cancer (Salama et al., 2002; Masetti et al., 2003). However, other studies suggest that the absence of this gene is associated with a lower risk of damage and disease (Li et al., 2000; Olshan et al., 2003).

The GSTM1 enzyme detoxifies products of oxidative stress and other reactive compounds (Seidegård et al., 1988). In white populations, approximately $50 \%$ of individuals are homozygous for the deletion polymorphism of GSTM1 (Rebbeck, 1997), which is also consistent with our results $(32.5,45$, and $48.1 \%$ in the control, T2DM, and CVD/T2DM groups, respectively; Table 2). It has been demonstrated that individuals carrying the null GSTM1 allele are more susceptible to inflammatory pathologies and at increased risk of some smoking-related cancers. Smokers that lack the GSTM1 gene develop both CHD and atherosclerosis at higher rates (Salama et al., 2002; Masetti et al., 2003). Conversely, this hypothesis has been rejected in other studies, in which the null GSTM1 genotype has been associated with lower risk of myocardial infarction and peripheral vascular disease (Wilson et al., 2000, 2003).

In the current study, we categorized our study participants as currently smoking cigarettes, having quit, or having never smoked. However, no statistically significant difference relating to smoking status was observed between the control, T2DM, and T2DM/CVD groups $(P=0.075)$, nor within them $(P>0.05)$. On the other hand, the majority of subjects in our study $(68.5 \%)$ had never smoked cigarettes, and $20.6 \%$ had not smoked for more than one year, indicating a positive lifestyle choice on the part of Malaysian diabetes sufferers, regardless of CVD complications. 


\section{Conflicts of interest}

The authors declare no conflict of interest.

\section{ACKNOWLEDGMENTS}

The authors would like to express their appreciation to all of the volunteers who participated in this research, and are thankful for the grants provided by Universiti Putra Malaysia.

\section{REFERENCES}

Amer MA, Ghattas MH, Abo-Elmatty DM and Abou-El-Ela SH (2011). Influence of glutathione S-transferase polymorphisms on type-2 diabetes mellitus risk. Genet. Mol. Res. 10: 3722-3730.http://dx.doi.org/10.4238/2011.October.31.14

Benhamou S, Lee WJ, Alexandrie AK, Boffetta P, et al. (2002). Meta- and pooled analyses of the effects of glutathione S-transferase M1 polymorphisms and smoking on lung cancer risk. Carcinogenesis 23: 1343-1350.http://dx.doi. org/10.1093/carcin/23.8.1343

Doney AS, Lee S, Leese GP, Morris AD, et al. (2005). Increased cardiovascular morbidity and mortality in type 2 diabetes is associated with the glutathione S transferase theta-null genotype: a Go-DARTS study. Circulation 111: 2927-2934.http:// dx.doi.org/10.1161/CIRCULATIONAHA.104.509224

Eaton DL and Bammler TK (1999). Concise review of the glutathione S-transferases and their significance to toxicology. Toxicol. Sci. 49: 156-164.http://dx.doi.org/10.1093/toxsci/49.2.156

Etemad A, Ramachandran V, Pishva SR, Heidari F, et al. (2013). Analysis of Gln223Agr polymorphism of Leptin Receptor Gene in type II diabetic mellitus subjects among Malaysians. Int. J. Mol. Sci. 14: 19230-19244.http://dx.doi.org/10.3390/ ijms140919230

Forsberg L, de Faire $U$ and Morgenstern R (2001). Oxidative stress, human genetic variation, and disease. Arch. Biochem. Biophys. 389: 84-93.http://dx.doi.org/10.1006/abbi.2001.2295

Grundy SM (2008). Metabolic syndrome pandemic. Arterioscler. Thromb. Vasc. Biol. 28: 629-636.http://dx.doi.org/10.1161/ ATVBAHA.107.151092

Haghvirdizadeh P, Ramachandran V, Etemad A, Heidari F, et al. (2015). Association of ATP-Binding Cassette Transporter A1 Gene Polymorphisms in Type 2 Diabetes Mellitus among Malaysians. J. Diabetes Res. 2015: 289846.http://dx.doi. org/10.1155/2015/289846

Hani $\mathrm{H}$, Ibrahim TA, Othman AM, Lila MA, et al. (2010). Isolation, density purification, and in vitro culture maintenance of functional caprine islets of Langerhans as an alternative islet source for diabetes study. Xenotransplantation 17: 469-480. http://dx.doi.org/10.1111/j.1399-3089.2010.00616.x

Hashibe M, Brennan P, Strange RC, Bhisey R, et al. (2003). Meta- and pooled analyses of GSTM1, GSTT1, GSTP1, and CYP1A1 genotypes and risk of head and neck cancer. Cancer Epidemiol. Biomarkers Prev. 12: 1509-1517.

Hatin W, Nur-Shafawati A, Etemad A, Jin W, et al. (2014). A genome wide pattern of population structure and admixture in peninsular Malaysia Malays. HUGO J. 8: 5. http://dx.doi.org/10.1186/s11568-014-0005-z

Hayes JD and McLellan LI (1999). Glutathione and glutathione-dependent enzymes represent a co-ordinately regulated defence against oxidative stress. Free Radic. Res. 31: 273-300.http://dx.doi.org/10.1080/10715769900300851

Hori M, Oniki K, Ueda K, Goto S, et al. (2007). Combined glutathione S-transferase T1 and M1 positive genotypes afford protection against type 2 diabetes in Japanese. Pharmacogenomics 8: 1307-1314.http://dx.doi.org/10.2217/14622416.8.10.1307

Jacobsen BK, Bønaa KH and Njølstad I (2002). Cardiovascular risk factors, change in risk factors over 7 years, and the risk of clinical diabetes mellitus type 2. The Tromsø study. J. Clin. Epidemiol. 55: 647-653.http://dx.doi.org/10.1016/S08954356(02)00404-3

Johns LE and Houlston RS (2000). Glutathione S-transferase mu1 (GSTM1) status and bladder cancer risk: a meta-analysis. Mutagenesis 15: 399-404.http://dx.doi.org/10.1093/mutage/15.5.399

Ketterer B, Harris JM, Talaska G, Meyer DJ, et al. (1992). The human glutathione S-transferase supergene family, its polymorphism, and its effects on susceptibility to lung cancer. Environ. Health Perspect. 98: 87-94.http://dx.doi. org/10.1289/ehp.929887

La Torre G, Boccia S and Ricciardi G (2005). Glutathione S-transferase M1 status and gastric cancer risk: a meta-analysis. Cancer Lett. 217: 53-60.http://dx.doi.org/10.1016/j.canlet.2004.08.020

Letchuman GR, Wan Nazaimoon WM, Wan Mohamad WB, Chandran LR, et al. (2010). Prevalence of diabetes in the malaysian national health morbidity survey III 2006. Med. J. Malaysia 65: 180-186. 
Li R, Boerwinkle E, Olshan AF, Chambless LE, et al. (2000). Glutathione S-transferase genotype as a susceptibility factor in smoking-related coronary heart disease. Atherosclerosis 149: 451-462.http://dx.doi.org/10.1016/S0021-9150(99)00483-9 Malaysian Ministry of Health (2008). Third National Health Morbidity Survey 2006. NHMS III Report, Malaysia. Available at [http://psasir.upm.edu.my/6543/1/supplement.pdf].

Masetti S, Botto N, Manfredi S, Colombo MG, et al. (2003). Interactive effect of the glutathione S-transferase genes and cigarette smoking on occurrence and severity of coronary artery risk. J. Mol. Med. 81: 488-494.http://dx.doi.org/10.1007/ s00109-003-0448-5

Ntais C, Polycarpou A and loannidis JP (2005). Association of GSTM1, GSTT1, and GSTP1 gene polymorphisms with the risk of prostate cancer: a meta-analysis. Cancer Epidemiol. Biomarkers Prev. 14: 176-181.

Olshan AF, Li R, Pankow JS, Bray M, et al. (2003). Risk of atherosclerosis: interaction of smoking and glutathione S-transferase genes. Epidemiology 14: 321-327.http://dx.doi.org/10.1097/01.EDE.0000059229.74889.CF

Pearson WR, Vorachek WR, Xu SJ, Berger R, et al. (1993). Identification of class-mu glutathione transferase genes GSTM1GSTM5 on human chromosome 1p13. Am. J. Hum. Genet. 53: 220-233.

Pemble S, Schroeder KR, Spencer SR, Meyer DJ, et al. (1994). Human glutathione S-transferase theta (GSTT1): cDNA cloning and the characterization of a genetic polymorphism. Biochem. J. 300: 271-276.http://dx.doi.org/10.1042/bj3000271

Ramprasath T, Senthil Murugan P, Prabakaran AD, Gomathi P, et al. (2011). Potential risk modifications of GSTT1, GSTM1 and GSTP1 (glutathione-S-transferases) variants and their association to CAD in patients with type-2 diabetes. Biochem. Biophys. Res. Commun. 407: 49-53.http://dx.doi.org/10.1016/j.bbrc.2011.02.097

Rebbeck TR (1997). Molecular epidemiology of the human glutathione S-transferase genotypes GSTM1 and GSTT1 in cancer susceptibility. Cancer Epidemiol. Biomarkers Prev. 6: 733-743.

Sadi G, Yilmaz O and Güray T (2008). Effect of vitamin C and lipoic acid on streptozotocin-induced diabetes gene expression: mRNA and protein expressions of Cu-Zn SOD and catalase. Mol. Cell. Biochem. 309: 109-116.http://dx.doi.org/10.1007/ $\underline{\text { s11010-007-9648-6 }}$

Salama SA, Au WW, Hunter GC, Sheahan RG, et al. (2002). Polymorphic metabolizing genes and susceptibility to atherosclerosis among cigarette smokers. Environ. Mol. Mutagen. 40: 153-160.http://dx.doi.org/10.1002/em.10106

Seidegård J, Vorachek WR, Pero RW and Pearson WR (1988). Hereditary differences in the expression of the human glutathione transferase active on trans-stilbene oxide are due to a gene deletion. Proc. Natl. Acad. Sci. USA 85: 72937297.http://dx.doi.org/10.1073/pnas.85.19.7293

Sull JW, Ohrr H, Kang DR and Nam CM (2004). Glutathione S-transferase M1 status and breast cancer risk: a meta-analysis. Yonsei Med. J. 45: 683-689.http://dx.doi.org/10.3349/ymj.2004.45.4.683

't Hoen PA, Rosema BS, Commandeur JN, Vermeulen NP, et al. (2002). Selection of effective antisense oligodeoxynucleotides with a green fluorescent protein-based assay. Discovery of selective and potent inhibitors of glutathione S-transferase Mu expression. Eur. J. Biochem. 269: 2574-2583.http://dx.doi.org/10.1046/j.1432-1033.2002.02924.x

Vogl FD, Taioli E, Maugard C, Zheng W, et al. (2004). Glutathione S-transferases M1, T1, and P1 and breast cancer: a pooled analysis. Cancer Epidemiol. Biomarkers Prev. 13: 1473-1479.

Whiting DR, Guariguata L, Weil C and Shaw J (2011). IDF diabetes atlas: global estimates of the prevalence of diabetes for 2011 and 2030. Diabetes Res. Clin. Pract. 94: 311-321.http://dx.doi.org/10.1016/j.diabres.2011.10.029

Wilce MC and Parker MW (1994). Structure and function of glutathione S-transferases. Biochim. Biophys. Acta 1205: 1-18. Wilson MH, Grant PJ, Hardie LJ, and Wild CP (2000). Glutathione S-transferase M1 null genotype is associated with a decreased risk of myocardial infarction. FASEB J. 14: 791-796.

Wilson MH, Grant PJ, Hardie LJ and Wild CP (2000). Glutathione S-transferase M1 null genotype is associated with a decreased risk of myocardial infarction. FASEB J. 14: 791-796.

Wilson MH, Grant PJ, Kain K, Warner DP, et al. (2003). Association between the risk of coronary artery disease in South Asians and a deletion polymorphism in glutathione S-transferase M1. Biomarkers 8: 43-50.http://dx.doi. org/10.1080/1354750021000042439

Ye Z and Parry JM (2003). A meta-analysis of 20 case-control studies of the glutathione S-transferase M1 (GSTM1) status and colorectal cancer risk. Med. Sci. Monit. 9: SR83-SR91.

Ye Z, Song H and Guo Y (2004). Glutathione S-transferase M1, T1 status and the risk of head and neck cancer: a metaanalysis. J. Med. Genet. 41: 360-365.http://dx.doi.org/10.1136/jmg.2003.016246

Zeggini E, Scott LJ, Saxena R, Voight BF, et al.; Wellcome Trust Case Control Consortium (2008). Meta-analysis of genomewide association data and large-scale replication identifies additional susceptibility loci for type 2 diabetes. Nat. Genet. 40: 638-645.http://dx.doi.org/10.1038/ng.120 